\title{
Perceptions of thermal comfort and housing quality: exploring the micro-geographies of energy poverty in Stakhanov, Ukraine ${ }^{1}$
}

\section{Authors}

\author{
Saska Petrova (s.petrova@bham.ac.uk) ${ }^{1}$ \\ Michael Gentile (michael.gentile@geography.umu.se) ${ }^{2,3}$ \\ Ilkka Henrik Mäkinen (ilkka.makinen@sh.se) ${ }^{2}$ \\ Stefan Bouzarovski (s.bouzarovski@bham.ac.uk) 1, corresponding author \\ ${ }^{1}$ School of Geography, Earth and Environmental Sciences, University of \\ Birmingham, Edgbaston, \\ ${ }^{2}$ Stockholm Centre on Health of Societies in Transition (SCOHOST), Södertörn \\ University, SE-14189 Huddinge, Sweden, \\ ${ }^{3}$ Umeå University, SE-90187 Umeå, Sweden,
}

\begin{abstract}
The growing recognition of the importance of indoor environments as 'active political-ecological spaces' (Day Biehler and Simon, 2010) has rarely been followed up by a systematic empirical engagement with the constituent dynamics and conceptual issues associated with infrastructural deprivation in this domain, particularly in non-Western contexts. Therefore, this paper investigates the relationship between self-reported perceptions of thermal comfort in the home, on the one hand, and a range of socio-demographic, housing, and health-related variables, on the other, via a quantitative analysis of a large-scale survey undertaken in the Eastern Ukrainian town of Stakhanov. Using the perceived level of thermal comfort as a starting point for its empirical explorations, the paper estimates the number and type of households who feel that they are receiving inadequate energy services in the home. Special attention is paid to the role of buildings in shaping the perceptions of thermal comfort.
\end{abstract}

Keywords: energy poverty, housing, thermal comfort, quantitative research, Ukraine

\section{Introduction}

The factors and dynamics that contribute to the rise of domestic energy deprivation in various geographical contexts are gaining increasing attention among policy practitioners and academic scholars. Understood as a condition in which a household

\footnotetext{
1 The authors wish to thank the Baltic Sea Foundation for generously supporting the project 'Health and Population Developments in Eastern Europe in the Conditions of Economic Crisis'. Part of Stefan Bouzarovski's work on this paper was funded by a Guest Professorship at the Centre for Baltic and East European Studies at Södertörn University College. Additional support was provided by the Ministry of Education, Youth and Sports of the Czech Republic (project no. MSM0021620831: 'Geographic Systems and Risk Processes in the Context of Global Change and European Integration'), and by the Interdisciplinary Cluster on Energy Systems, Equity and Vulnerability, via the UK Research Councils’ Energy Programme (grant no: EP/G040176/1).
} 
lacks a socially and materially necessitated level of energy services in the home (based on Buzar 2007a) energy poverty is present in developed and developing countries alike. In the global North, the predicament is also described as 'fuel poverty' and is frequently the subject of remedial or preventative measures generated by the state; this is particularly true in the UK, where, following Boardman's (1991) seminal contribution, an extensive body of research has documented and explored the causes of the difficulties faced by households who are unable to afford an adequate level of thermal comfort in the home. In the global South, energy poverty is mainly seen as a function of inadequate access to energy services in homes and communities, resulting from the lack of infrastructure and economic development (Pachauri, 2004; Sagar, 2005).

There is no consensus in the literature regarding the most effective method of establishing which households suffer from energy poverty. Experts and governments in developed-world countries have been grappling with this problem for a considerable time, given the impracticalities of direct house-to-house measurement of the quality of energy services, and its relationship to contributing factors such as income, demography, or energy efficiency (see, for example, Healy, 2004; Buzar 2007a). As a result, the level of energy expenditure is often used as a proxy for energy poverty, which means that households are considered energy-poor if they have to spend a certain share of their income for energy, or if they have incurred a loss of welfare as a result of a upward change in energy prices. While this approach allows for relatively simple large-scale explorations and comparisons of the causes of, and trends in, energy deprivation, it does have a number of deficiencies: energy expenditure does not necessarily correspond to the final energy service received by the household, which is in itself affected by the efficiency of the built fabric, heating systems, and appliances of the home; also, there is no consensus about the equivalence scales that should be used to account for the economies of scale that larger households can achieve when using energy in a single dwelling (ibid; and Boardman, 2010).

As a result, some authors advocate the use of self-reported indicators to measure energy poverty. This effectively means that a household will be seen as suffering from energy poverty whenever it responds affirmatively to a question about the lack of adequate energy services in the home. Subjective energy poverty indicators have been used by a number of academics and large panel studies. They form the basis for some of the data gathered in the European Union Statistics on Income and Living Conditions, which provides data on variables such as 'ability to keep the home adequately warm' and 'arrears on utility bills', in addition to a range of housing indicators. Similar statistics were gathered within the European Community Household Panel, which ran between 1994 and 2001. This means that comparative self-reported poverty indicators have been available on an annual basis at the EU level for more than 15 years.

However, the methodological and epistemological implications of using subjective perceptions of thermal comfort or energy affordability are poorly understood. It remains unclear how self-reported views of indoor warmth relate to other residential satisfaction indicators. The cultural dimensions of using such personal understandings are also unclear - especially as it is known that a home normally considered well-lit and warm in one geographical context may not be seen as such in another (Wilhite et 
al., 1996). Building scientists have often relied on the 'adaptive model' of thermal comfort, which postulates 'that contextual factors and past thermal history modify building occupants' thermal expectations and preferences' (de Dear and Brager, 1998: 145). More recent social science-based work in this vein has explored the 'new context for comfort' created by the movement towards a low carbon society (Cole et al. 2008: 323), partly by questioning whether cultural expectations and norms may be too high in the present setting (Moezzi, 2009). A related body of scholarship has also explored the multiple socio-cultural and technical conditionings involved in defining, inter alia, thermal comfort standards in residential, public and commercial buildings (Shove, 2003; Corgnati et al., 2007; Hitchings, 2009).

Very few of these studies, however, have made an explicit link to issues of fuel poverty. Within the European space, the establishment of such conceptual connections is particularly pertinent in light of the great differences in self-reported energy poverty indicators evident from the SILC survey - the share of the population which thinks that it is 'unable to keep the home adequately warm' has ranged from 64.2 per cent in Bulgaria to 0.3 in Luxembourg. In this context, it is worth noting that the average percentage of people reported to be living in this condition in the postcommunist 'EU-10' members in Central and Eastern Europe (CEE) is 16.7, while the equivalent figure for the rest of the EU is 6.8. While cultural differences may partly explain this gap, it is most likely due to the significantly greater prevalence of energy poverty in CEE, as a result of the overall low incomes of the population, the removal of energy tariff subsidies inherited from communist central planning - resulting in significant price increases over the past 20 years - and the low energy efficiency of the housing stock (Buzar, 2007a; 2007b; 2007c).

Therefore, this paper investigates the relationship between self-reported perceptions of thermal comfort in the home, on the one hand, and a range of socio-demographic, housing, and health-related variables, on the other, via a quantitative analysis of a large-scale survey undertaken in the Eastern Ukrainian town of Stakhanov. The selection of such a geographical setting is, in part, due to some of the contingencies outlined above: despite receiving a minimal amount of academic interest - especially in terms of self-reported energy poverty indicators - the city lies in a part of the world where a significant part of the population is likely to be suffering from domestic energy service deprivation. Using the perceived level of thermal comfort as a starting point for its empirical investigation, the aim of the paper is to estimate the number and type of households who feel that they are receiving inadequate energy services in the home. Special attention is paid to the role of buildings in shaping the relationship between thermal comfort and the socio-cultural features of the household, as a starting point for understanding how the political ecologies of indoor environments (Day Biehler and Simon, 2010) are implicated in the functioning of built and social formations at different scales.

The paper commences with an overview of the key literatures on the dynamics that produce energy poverty, focusing, in particular, on studies that have used subjective measures to explore the lack of thermal comfort in the home. There is also a discussion of the more specific features of domestic energy deprivation in the postcommunist context. This is followed by a more detailed overview of the conditions in Ukraine and Stakhanov itself, which serves as a starting point for presenting the main methods and research design of the study. We then outline our key empirical findings, 
by exploring the multiple ways in which self-reported perceptions of thermal comfort correlate with selected social, economic, cultural, and housing features. The conclusion of the paper delineates some of the theoretical and practical implications of interpreting the constitutive dynamics of energy poverty in post-socialist CEE through the lens of subjective wellbeing.

\section{Setting the context: the variegated geographies of energy poverty}

The overwhelming majority of academic work on energy poverty in the developed world has been produced in, and pertains to, the UK and Ireland. This is largely the result of a rare combination of expert-led research and public advocacy, which brought the plight of Britain's 'fuel-poor' households to the fore more than 40 years ago (Boardman, 1991; Healy and Clinch, 2002). From the position of having its existence denied outright by a government minister with the words "people do not talk of "clothes poverty" or "food poverty" and I do not think that it is useful to talk of "fuel poverty" either' (Campbell, 1993: 58), fuel poverty is now of central public concern in the UK; it is frequently the subject of front-page headlines in the top daily newspapers, an important political battleground at different scales of decisionmaking, and the subject of numerous academic research projects and publications (see Boardman 2010).

The prominence of fuel poverty in these two countries, however, is not simply the result of a successful alignment of expert opinion and political action; at its source lie the day-to-day difficulties faced by millions of households living in cold homes. The extensive nature of fuel poverty in Ireland and the UK largely stems from the idiosyncracies of the two countries' social makeup and residential buildings. Both states possess above-average levels of income inequality, which has meant that disproportionately large parts of their populations have been exposed to post-1970 energy price increases. Perhaps more importantly, the housing stock in both countries has historically been of the worst quality in Western Europe, particularly in terms of thermal efficiency (Healy, 2004). As evidenced by the rate of excess winter deaths considered by many to provide a good indication of inadequate thermal comfort in the home (ibid) - these two factors have resulted in record levels of fuel poverty in the UK and Ireland alike.

Academic research on fuel poverty in these two countries has highlighted, inter alia, its intersections with low incomes (Milne and Boardman, 2000), built form, and inefficient homes (Wright, 2008; Nevin, 2010), housing tenure (Hong et al., 2009), heating systems (Walker, 2008), and socio-demographic circumstances such as household size, gender, class, or education (Wright, 2004; Critchley et al., 2007). Authors working in this vein have emphasized the above-average rates of energy and fuel poverty among older people (Ekamper et al., 2009), families with children (Liddell and Morris, 2010), and households with disabilities, long-term illness, or infirmity (Cheshire, 2009). They have explored the multiple health consequences of inadequately heated homes (Harrington et al., 2005) and their relationship with energy efficiency interventions and technical systems (Heyman et al., 2005; Stewart and Habgood, 2008). More recent work on the issue has started to conceptualise energy poverty with the aid of a vulnerability framework, which has helped highlight the critical pathways that may tip households into deprivation, while emphasizing the social, political and infrastructural complexities involved in constructing the lack of 
thermal comfort in the home (Bouzarovski et al., 2011). Some of this research has drawn on Sen's ( capabilities framework, highlighting the justice dimensions of distribution, procedure and recognition enmeshed in the rise of fuel poverty (Walker and Day, 2012).

Much of this research has drawn on the limited body of work that has explored the adequacy of energy services in the home - particularly heat - with the aid of selfreported indicators. This includes Healy and Clinch's (2002) seminal work on the relationship between fuel poverty, inadequate thermal comfort and household occupancy in Ireland. Using a combination of subjective and objective measures of thermal comfort, the two researchers established that "two-thirds of fuel-poor householders demonstrate cold strain, and over half of elderly households endure inadequate ambient household temperatures during winter' (page 329). The same two authors (see Healy and Clinch, 2004) have also used this survey to comprehensively explore the severity and socio-spatial features of fuel poverty in Ireland. Here, they use a four-category response variable to classify answers to the question asking 'all households in the sample to state how often they were unable to adequately heat their home' (page 209), arguing that the binary-response question used by the European Community Household Panel only captures 'persistent' as opposed to 'intermittent' fuel poverty. Healy (2004) has used data from this panel to publish one of the very few books on fuel poverty at the European level, which also provides a detailed elaboration of the 'consensual approach' in the context of fuel poverty measurement. According to him, this 'employs indicators of socially perceived necessities', but 'unlike traditional forms of measuring relative poverty, this approach does not rely on the opinions or scientific postulates of academics or experts' (page xii); assessments of poverty and comfort are made on a bottom-up basis, by the respondents themselves.

A similar approach - but using a dichotomous variable to code the level of domestic warmth - can be found in Burholt and Windle's (2006) study of the relationship between perceived thermal comfort, income, expenditure, and housing quality in the homes of older people in North Wales. In their case, self-reporting also extends to a wider range of housing variables such as the age of the dwelling, and the presence of 'roof insulation, draught proofing, double glazing, hot water tank insulation, cavity wall insulation or central heating' (page 1201). However, other than Healy (2004) neither this nor any of the other studies listed above contain any significant amount of critical reflection on the challenges associated with using self-reported fuel poverty indicators to investigate the condition. This is despite the fact that the broader methodological aspects of this approach have been discussed extensively in the academic literature (see, for example Kapteyn et al., 1988; Spector, 1994), often within the context of debates about the 'consensual' poverty-measuring paradigm (Walker, 1987; McKay, 2004).

Even though CEE countries are likely to contain much higher numbers of energy-poor households - in both relative and absolute terms - compared to any other part of Europe, academic research on the topic has been limited. As was briefly pointed out above, these states inherited a specific pricing structure from communist-era central planning, with energy prices for industry being higher than those for households effectively amounting to a indirect cross subsidy from the former towards the latter (Gray, 2005). At the same time, the entire energy sector was in state hands, and all oil, 
gas, electricity and district heat operations were vertically and horizontally integrated. Such policies were part of the socialist ideology of prioritizing heavy industrial development and defence concerns over all other economic policies, while treating access to energy as a basic entitlement rather than a service associated with a price tag (Stern and Davis, 1998; Borén and Gentile, 2007).

This approach could not withstand the pressure to move towards a market-based economy after the fall of communism. Not only did states quickly increase and 'rebalance' their energy tariffs - partly under the influence of international organizations such as the World Bank, the European Bank for Reconstruction and Development and even the European Union - but they also unbundled and privatized energy companies, opening the industry up to competition. The concurrent rise in income inequality and overall poverty, alongside the initial lack of concerted efforts to improve the energy efficiency of rapidly decaying housing stocks and energy infrastructures, meant that energy poverty quickly took hold over large parts of the population. It is estimated that millions of households are presently suffering from a lack of adequate domestic energy services (particularly space heating and cooling, lighting, as well as cooking) in CEE. This is particularly true in the lesser-developed states of the Balkans, where energy deprivation is also predicated upon issues of access to energy infrastructure (Kovačević, 2004; Wu et al., 2004; Buzar, 2007a; 2007b; 2007c).

It should be pointed out that the many republics of the Former Soviet Union (FSU) particularly those located in Central Asia and the Caucasus - are a rather special case in terms of the socio-spatial extent of inadequately heated homes. The severity of domestic energy deprivation in such countries has often been of a 'potential' character (Buzar, 2007a), since states have maintained price subsidies for energy while failing to invest in energy efficiency - suggesting that the problem will expand in the future if price subsidies are lifted. Many FSU countries - excluding the Baltics - have been reluctant to follow the standard neoliberal reform formula, by failing to relinquish state control over energy companies and removing cross-subsidies for energy; according to von Hirschhausen and Wälde (2001) they have developed either a 'postSoviet mixed' or a 'Caspian state' economic regime in the regulation of the postcommunist energy sector. A different situation has transpired in most CEE states, where patterns of energy poverty are either of an 'insular' or 'pervasive' nature depending on governments' abilities to address the dual challenge of improving the efficiency of the housing stock while providing adequate social safety nets for low income households: energy poverty has affected selected demographic groups in 'insular' states, as opposed to being extensively present among the entire population in 'pervasive' cases.

Despite significant increases of electricity, gas and district heat tariffs during the past 20 years, the Ukrainian energy sector has nevertheless retained various elements of the post-Soviet energy regulation regime. Indirect price subsidies, particularly in electricity, are still present; Dodonov et al. (2004) have estimated that the increase of electricity prices up to the 'long-run marginal cost' level - when cost recovery and profit can be achieved - would push a significant part of the population into 'severe social problems'. At the same time, 'non-payment for electricity consumed as well as pervasive non-monetary settlements have led to serious cash shortages in the sector 
causing fuel supply shortages' as well as 'frequent interruptions of the electricity supply' (page 856).

A similar situation can be found in the gas and district heating sectors; the state's reluctance to raise prices in the former lies at the heart of the well-publicized gas interruption events with Russia during recent years (Bassin and Bouzarovski, 2011). It is worth noting that electricity tariffs have more than doubled in real terms since 1999, partly aimed at addressing the fact that Ukraine had 'the world's lowest tariffs for electricity' (Tsarenko, 2007: 16) in 2005; according to the National Electricity Regulation Commission, electricity tariffs covered only 60 per cent of production costs in 2006 (ibid). The energy sector, otherwise, is controlled by a complex combination of state and private interests; most notably, the former owns and manages the country's four large nuclear power stations, eight hydroelectric plants, as well as the oil and gas networks. There are also 94 thermal power plants, six of which - representing approximately half of the total generating capacity - are privately owned and run. The national grid is controlled by the Ukrenergo state company, although the 27 regional electricity distribution companies are in private hands (AEA, 2012)

The lack of systematic energy efficiency improvements in the housing stock, coupled with the rapidly decreasing affordability of energy, suggest that Ukraine is hardly immune to the energy poverty-inducing dynamics so typical for many CEE countries. In this region, the absence of financial capital (both state and private) for investment in residential energy efficiency has been exacerbated by broader cultural and social factors that result in the relatively low prioritization of this activity in household decisions (Wu et al, 2004; Buzar, 2007). Neither private utilities nor the state have taken decisive action to address this situation, resulting in a slow decline of the energy efficiency of the energy efficiency of residential buildings during post-socialism.

\section{Housing and energy conditions in Stakhanov}

Stakhanov is a city of 80,000 inhabitants in the densely-populated Donbas region of Eastern Ukraine. Having been subject to severe industrial shrinkage and the disappearance of the coal mining sector since the demise of communist-era central planning, post-Soviet Stakhanov is a city that is rapidly depopulating as a result of natural decline and net out-migration of both seasonal and permanent character, Russia being the main migrant destination as is usually the case from Ukraine (see O'Hara et al., 2009; Gentile and Marcińczak 2012). The process is aided by the fact that the vast majority of Stakhanov's inhabitants are Russian speakers (as 95 per cent of the respondents in our survey stated that Russian is the first language they use at home).

Stakhanov's spatial structure is largely reminiscent of that of the 'classic' socialist mining town, effectively forming a fragmented conglomeration of several semiindependent coal mine settlements (see Pertsik, 1980; Domański, 1997) held together by one major transport route and a more developed central core. The central area used to concentrate the main ceremonial, administrative and retail functions of the previous regime. Much of the city's housing stock dates back to the Khrushchev era (19581964), which marked the beginning of the Soviet mass housing construction programme (Figure 1). The quality of the dwellings erected during this first stage is 
widely regarded as poorer than the output of the previous and following years (French 1995; Gentile and Tammaru, 2006).

Since the late 1960s, however, the city started to develop following a more integrally planned bi-polar concept, concentrating its population in two new high-rise housing estates, first at the northern and then at the southern end of the city (Figure 2). These areas continued to expand until the last days of the Soviet empire. Some of the housing in them was built using higher standards - more floor space, better quality insulation and infrastructure - than the structures dating from the Khrushchev period.

(insert Figures 1 and 2 about here)

As is usually the case elsewhere in the former communist realm, the Soviet-era housing districts are connected to the city's district heating network, with its typical lack of metering at the household/building level, as well as inefficient and decaying generation and transmission infrastructures (Poputoaia and Bouzarovski, 2010). Most of Stakhanov's population lives in apartment blocks of poor quality, especially in terms of their thermal efficiency. The remainder can be found, for the most part, in single-family housing built from the late nineteenth century onwards, of varying - but generally very low - quality and limited facilities; given the lack of building codes and standards during that period, it is likely that the efficiency of such dwellings is even lower than those in communist housing estates. Almost no residential buildings have been erected since 1991.

In its entirety, Stakhanov is representative of many medium-sized towns in postSoviet Ukraine and the economically disadvantaged regions of other CEE states. The combination of housing stock difficulties and energy reform challenges make it an ideal site for studying the household-level implications of the interactions between these two sets of issues. Exploring these issues through a systematic study is all the more pertinent in light of the fact that energy poverty in medium-sized post-Soviet towns has received very little academic attention.

\section{Methodological framework of the study}

The empirical analyses presented in this paper are based on data gathered in the 2009 Stakhanov Health Interview Survey (SHIS), which was conducted by the Stockholm Centre on Health of Societies in Transition (SCOHOST) in collaboration with the Luhansk oblast' statistical authority and the Stakhanov City Statistical Office. The survey was conducted on a representative sample of 3,000 of the 71,577 residents of the city of Stakhanov over the age of 18 between April and June 2009. The sampling frame consisted of a register of households created by merging dwelling unit information from different departments of the Stakhanov city administration; the interviewees within each household were selected according to the closest birthday method. Each interview lasted approximately one hour, covering about 100 different questions, and resulting in more than 300 variables in the final dataset. At 88.8 percent, the survey's response rate was high when compared to similar surveys conducted elsewhere in the Former Soviet Union (FSU). Compared to the official statistics, the sample was somewhat skewed towards women and older people. Even so, the analysis presented here is based on relationships between household attributes, with the demographics of the dwellers being controlled for, which means that the 
skewness should not cause too much distortion (for more on the specific methodological issues of the study, see Gentile et al., 2009; for the wider epistemological challenges associated with exploring post-communist poverty, health and housing with the aid of self-reported indicators see, for example, Gillan, 2000 and Vågero and Kislitsyna, 2005).

Our dependent variable was the level of perceived thermal comfort in the home. Building on Healy and Clinch (2002), interviewees were asked to state their opinion about whether the 'usual wintertime indoor temperature' in their home was '(a) too cold, (b) tolerably cold, (c) sufficiently warm, or (d) too warm'. The covariates captured demographic, material wealth, housing-related, socio-cultural and situational factors. Data supporting the latter - temperature and cloud cover (at $1 \mathrm{PM}$ ) on the day of the interview - were obtained from the Luhansk oblast' hydro-meteorological service, resting on the hypothesis that the current meteorological conditions may have influenced the respondents' perception of wintertime domestic warmth.

As regards the response alternatives to the perceived warmth question, only nine out of the 3,000 respondents thought their wintertime temperature indoors were 'too warm', so practically only three alternatives were left for analysis. Seeking to avoid the problematic distinction between 'too cold' and 'tolerably cold', it was decided to dichotomize the dependent variable into 'warmer' (answers 'c' and 'd' above) and 'colder' (answers ' $a$ ' and ' $b$ '). The dependent variable of the analysis, perceiving one's dwelling as being 'colder', was then analysed using binary logistic regression. The hypothetical determinants - a combination of self-reported and observed variables capturing demographics, material wealth, dwelling tenure status, objective housing quality, respondent characteristics, and interview situational (meteorological) factors - were then tested in six cumulative regression models.

\section{Socio-spatial underpinnings of self-reported thermal comfort: a quantitative investigation}

The descriptive statistics of the dependent variable (Table 1) suggest that an important share of the population perceived its typical indoor wintertime temperature as either tolerably (29.2 per cent) or too (14.5 per cent) low. It should be pointed out that 23.6 per cent of the respondents were one-person households, while 39.0 per cent were older than 60; a further 20.4 per cent were between the ages of 50 and 60 . The vast majority of those aged 60+, and almost half of those aged 50-59, consisted of nonworking pensioners. At the same time, 26.6 per cent of the respondents rated their health conditions as either poor or very poor. The overwhelming majority of dwellings in the sample were located in apartment blocks, as a mere 17 per cent of the respondents lived in single-family homes. The average total living space available to each person was 27 square metres. The housing stock in the sample was predominated by residential buildings constructed in the decades following the Second World War (Table 2).

It should be pointed out that 89 per cent lived in an owner-occupied dwelling - a rate somewhat higher than the national average, where the equivalent figure was slightly 
lower than 65 per cent in already in 2000 (see Tsenkova and Turner, 2004 ${ }^{2}$ ). Even though Ukraine has been quick to privatise its housing stock after 1990 - during socialism, the entire multi-family housing sector was owned and managed by state organizations - elements of the previous system still remain. In particular, governmental organizations still play a role in the allocation of municipally-owned housing (ibid). As has been the case elsewhere in CEE, ownership arrangements in apartment buildings have been a major obstacle towards housing refurbishment (Sýkora and Bouzarovski, 2012).

(insert Table 1 about here)

(insert Table 2 about here)

Table 3 shows the results of the first stage of our analysis in the form of bivariate logistic regressions of a range of independent variables against perceived wintertime thermal discomfort indoors. As can be seen, all of the selected variables produce statistically highly significant $(\mathrm{p}<0.001)$ crude effects on perceived temperature, with the presence of damp in the dwelling, the need to borrow money, living in Khrushchev-era housing and self-reported poor health (a variable that was constructed from the survey's question on self-rated health) being the strongest predictors, in the respective order.

Taking this further, Model 1 tests the effects of demographic factors (see Table 4). All variables produce significant results: women and older people are more prone to experience domestic thermal discomfort, while an increased household size helps reduce the severity of self-reported domestic energy deprivation. The effect of household size may also stem from the economies of scale achieved by a greater level of occupancy in a single dwelling (see Buzar, 2007a; Boardman, 2010). However, after introducing two material wealth indicators (income and the need to borrow money) in Model 2, the impact of gender disappears altogether. Income as such seems to increase warmth, and, conversely, the need to borrow money is related to a colder dwelling. Thus, differences in some of the key components of material wealth explain the effect of gender: it is likely that women experience discomfort to a greater degree because they cannot afford to heat their dwellings as a result of low incomes. Indeed, women in the study sample were significantly more likely to suffer from material deprivation (Table 5). This matches the more general situation in the Ukraine, where women have been consistently been shown to suffer from lower income levels since 1990, although such differentials seem to have been partly ameliorated after 2000 (Ganguli and Terrell, 2005).

(Insert Tables 3 to 5 about here)

Model 3 introduces the ownership status of the dwelling. It transpires that tenure strongly predicts greater thermal comfort without altering the impact of the demographic and material wealth variables substantially. Even though an overwhelming share of respondents lived in privately-owned housing, this suggests that the homes left under municipal administration are more poorly heated and/or that

\footnotetext{
${ }^{2}$ This is the most recent data for which systematic evidence is available; the national average is likely to have increased since this date, and probably resembles the observed figure in Stakhanov.
} 
private ownership encourages energy conservation measures or interventions in the efficiency of the built environment and heating system aimed at improving thermal conditions indoors. Moreover, while there certainly exists a correlation between owning one's dwelling and material wealth, it does not seem to play a significant role in the effect of ownership on thermal comfort.

In Model 4, selected dwelling characteristics are added: floor space, the presence of central heating, whether or not the dwelling was erected in the Khrushchev era, and whether or not the dwelling is perceived as humid by the respondent. Household size correlates with floor space and loses its significance, while dwelling ownership seems to correlate with better housing and loses some of its positive effect in this model. Central heating - which is likely to be entirely represented by district heating - does not appear as an important variable in its own right, probably because its role is overshadowed by the structural quality of the host building. This might be supplemented by the fact that apartments without central heating are likely to have independent heating systems that are at least as effective and that are frequently installed as an alternative (or complement) to central heating. Most notably, the presence of damp and, to a lesser extent, living in a Khrushchev-era building increase the level of self-reported cold in the home.

Model 5 introduces some additional respondent characteristics, in order to investigate the potential role of socio-cultural affiliations and self-reported health in influencing perceptions of thermal comfort. The first variable in this group, 'Born in Russia', is intended to capture potential differences in self-reporting stemming from a local versus a Russian birthplace - and, possibly, cultural background - while the second control variable pertains to self-rated health. The outcomes of this analysis suggest that even after controlling for age there still exists, amongst other characteristics, a significant effect of poor health on perceived cold. However, the Russian-born respondents are both older and have a poorer health than others, and the presumed cultural effect disappears when controlled for these and other variables in Model 5. This provides evidence about the similarity of perceptions of thermal comfort across national boundaries, thus strengthening the methodological validity of using selfreported indicators.

The final model (No. 6 in Table 4) introduces two situational factors relating to the meteorological conditions on the day the interview was conducted: daytime temperature and daytime cloud cover. This was done in order to test the assumption that the weather conditions on the day of the interview might, by affecting the actual indoor temperature and feel - possibly because a chilly spring day may have reminded the respondents about wintertime temperatures - have influenced the interviewees' memory of wintertime indoor temperature comfort levels. However, only cloud cover retained a significant effect when compared to the bivariate statistics (Table 3), with the sunniest days surprisingly yielding the coldest wintertime memories. There may be an indirect effect of temperature here after all: while the temperature variable is based on official measurements made at $1 \mathrm{PM}$, Stakhanov is subject to continental climatic conditions that are usually associated with large daily temperature excursions and cold nights in particular, when there is little or no cloud cover. The effect of microclimatic conditions is particularly strong during early spring: according to data provided by the Luhansk oblast hydro-meteorological service during the survey period, the temperatures at 1 PM during April 2009 varied 
between 6.3 and 24.8 degrees Celsius, while the nights frequently offered sub-zero temperatures.

\section{Identifying the energy poor}

Summing up the final model (6), we may identify material wealth (expressed both as income and in relation to the need to borrow money) as well as tenure and objective characteristics of the dwelling (except the presence of central heating) as important independent contributors to the perception of wintertime indoor thermal comfort. The respondent's age and perceived health also contribute to the perceived lack of heating services in the home, but only to a moderate extent. In the literature on fuel poverty in other geographical contexts, it has been established that households with more sedentary lifestyles face an elevated risk of falling into fuel poverty because their higher demand for heating increases the burden of energy costs on the family budget (Wright, 2004; Boardman, 2010)

As far as the dwelling characteristics are concerned, it is notable that private ownership and a large living space - in relative terms at least - help decrease the likelihood of an insufficiently warm dwelling, while living in a building from the Khrushchev era or, most notably, one that is perceived as being humid lead to lower levels of perceived thermal comfort.

Overall, these results chime in with the outcomes of similar studies in Western and Eastern European countries, which have shown a close relationship between energy poverty and energy efficiency; in our model, the latter may be indicated by the presence of damp in the home, and the (probably) higher levels of useful heat loss in Khrushchev housing. The fact that the need to borrow money, rather than absolute income, is a better predictor of energy poverty is interesting but not surprising, given the frequent under-reporting of income in post-communist states, and the widespread reliance on non-monetary sources of subsistence; the link between energy poverty and poor health is well established (Boardman, 2010; Liddell, 2010).

The relatively strong link between variables pertinent to the quality of the built environment, on the one hand, and those describing perceived levels of indoor warmth, on the other, is an indicator of the relative affordability of energy in the Ukraine. Given the results of work by authors such as Dodonov et al. (2004) it can be expected that income will play a stronger role in influencing energy poverty after an increase of electricity and gas tariffs to cost recovery levels; the continued persistence of the 'post-Soviet mixed economy' in the energy sector has obviously prevented this from happening to date. A further contributing factor is the low residential mobility of the population, creating situations where households are 'trapped' in dwellings that are expensive to heat (Tirado Herreto and Ürge-Vorsatz, 2011).

With the help of the final model, the majority of those experiencing cold in their dwellings can be placed in the correct category. Considering the ends of the scales, the differences appear much more clearly: thus, 80 out of the 91 persons whose households earn more than 2700 UAH per month, and who own their (in Stakhanov terms) relatively large ( $>64$ square metre) dwelling experience a warm indoor environment in the winter. At the other end, none of the 22 persons who earn less than 1227.5 UAH per month and rent their relatively small ( $<44$ square metre) dwelling 
are in such a situation. These differences, despite being relatively small in absolute terms, turn out to predict major differences in living conditions.

\section{Conclusion}

The evidence reviewed in this paper has illuminated some of the factors that contribute to the rise of domestic energy deprivation in Ukraine, where inadequately heated homes have become a part of everyday reality. Almost half of the households in our sample felt that that the daytime temperature in their dwelling was insufficiently high, with nearly 15 per cent qualifying it as 'too low'. This situation has transpired despite the fact that the Ukraine has been slow to increase energy prices and reform its energy sector along the lines of the neoliberal restructuring path pursued in CEE states further west. Our investigations have highlighted the crucial role of inefficient housing in producing energy poverty, as evidenced by the perception of humid air, as well as the link between perceived cold and living in poor quality Khrushchev-era housing. The main mediating mechanism in this context seems to be the poor thermal efficiency of the building envelope, stemming from the lack of financial capital for housing renovation, as well as broader regulatory conditions in the energy sector.

Other important factors include low income - particularly being in debt - and renting one's apartment, as well as, to a lesser extent, older age. In terms of their generic features, therefore, energy poor households in Stakhanov are not very different from those suffering from a lack of thermal comfort in other Western and Eastern European countries (Healy 2004). But the method of self-reporting in assessing the indoor heating levels has also brought up a number of local idiosyncracies that may be replicated elsewhere in post-Soviet states and even CEE. It has transpired that a household's need to borrow money in the recent past is a much better predictor of inadequate thermal comfort than declared income levels - this may be attributed to the relative unreliability of reported income, as well as the possibility that perceived thermal comfort does not increase beyond a certain income level. Interestingly, the presence of central heating in the home does not make any difference in this regard, probably as a result of the specific socio-technical assemblage (Harrison and Popke 2011) that characterizes the Ukrainian energy sector: an interweaving web of heterogeneous energy circulations implicated in the operations of a wide range of private and public actors, where the failure of large-scale infrastructures to deliver reliable energy services is commonplace.

At the same time, factors that might have influenced the nature of a household's subjective perception of the level of warmth in the home - such as daytime temperature on the day of the interview, or the respondents' cultural background have also been shown to play an insignificant role; it should be noted, however, that different results could have been generated if the survey was undertaken in a different season of the year, and that our research methodology is unable to provide in-depth insights into the socio-cultural underpinnings of perceptions of thermal comfort. But the significant effects of older age and self-reported poor health indicate that immobility and weak circulation are some of the mechanisms that explain the lack of thermal comfort. It should be noted that the effects of age and health persist even when controlled for each other. 
When placed in the context of the methodological debates surrounding the measurement of energy poverty, the results of our study demonstrate the benefits of relying on self-reported indicators to assess energy poverty in the home. The fact that energy efficiency has been shown to play a major role in the rise of energy poverty in our sample, in particular, lends credence to the use of subjective measures in this context. Arguments in favour of the self-reporting approach are further strengthened by the logistical difficulties associated with providing objective and reliable measurements of domestic thermal comfort, the energy efficiency of dwellings, and the inability to pay energy bills in geographical settings such as those of Stakhanov. Nevertheless, there are some important caveats here - a quantitative analysis of energy poverty patterns on the basis of self-reported measures can only provide a generalized perspective on the issue. The use of 'qualitative approaches with groups of current users' (Hitchings 2009: 89) would be necessary to identify the multiple sensibilities and nuances involved in the micro-scale conditioning of thermal comfort. In terms of the energy poverty-relevant metrics of justice identified by authors such as Walker and Day (2012), we would argue that consensual approaches are best suited to explore distributional and recognition issues. While a quantitative analysis is best suited to the investigation of the former (by identifying vulnerable groups), qualitative methods should provide useful insights into the norms and conditionings involved in determining which groups in society are recognized as suffering from fuel poverty, and considered 'deserving' of state assistance.

The various lines of evidence emerging from this paper have also brought to the fore the multi-layered nature of the 'geographies of energy poverty' in the former Soviet Union and CEE, and the need for developing research agendas that can adequately consider the place- and people-specific features of inadequate domestic thermal comfort in spatial contexts where this condition is pervasive and severe. They have highlighted the complex political ecologies involved in constructing and reproducing domestic energy deprivation, including the governance of the energy sector (reflected in the state's inability to deliver reliable energy services and energy efficiency improvements) as well as housing regulation (entailing the institutional and material dimensions of housing refurbishment). It has also transpired perceptions of thermal comfort in the Ukrainian context involve a range of 'dynamic, integrated, and participatory aspects' (Cole et al. 2008: 323), exemplified by the multiple demographic and spatial factors involved in determining which households reported that their homes were insufficiently warm.

\section{References}

Austrian Energy Agency (AEA). (2007). Energy in Central and Eastern Europe. Retrieved 6th August, 2012, from http://www.eva.ac.at/enercee.

Biehler D D, Simon G L, 2010, "The Great Indoors: Research frontiers on indoor environments as active political-ecological spaces" Progress in Human Geography 35 172-192.

\section{Boardman B, 1991 Fuel Poverty: From Cold Homes to Affordable Warmth} (Bellhaven, London).

Boardman B, 2010 Fixing Fuel Poverty: Challenges and Solutions (Earthscan, 
London).

Borén T and Gentile M, 2007 "Metropolitan processes in post-communist states: an introduction" Geografiska Annaler B 89 95-110.

Bouzarovski S, Bassin M, 2011, "Energy and identity: Imagining nations through hydrocarbon flows" Annals of the Association of American Geographers available online DOI: 10.1080/00045608.00042011.00567942.

Bouzarovski S, Sarlamanov R, Petrova S, 2011 The Governance of Energy Poverty in Southeastern Europe (French Institute for International Relations, Brussels).

Burholt V, Windle G, 2006, "Keeping warm? Self-reported housing and home energy efficiency factors impacting on older people heating homes in North Wales" Energy Policy 34 1198-1208.

Buzar S, 2005, "The institutional trap in the Czech rental sector: Nested circuits of power, space and inequality" Economic Geography 82 381-405.

Buzar S, 2007a Energy Poverty in Eastern Europe: Hidden Geographies of Deprivation (Ashgate, Aldershot).

Buzar S, 2007b, "When homes become prisons: The relational spaces of post-socialist energy poverty" Environment and Planning A 39 1908-1925.

Buzar S, 2007c, “The 'hidden' geographies of energy poverty in post-socialism: Between institutions and households" Geoforum 38 224-240.

Campbell R, 1993, "Fuel poverty and government response" Social Policy \& Administration 27 58-70.

Cheshire P, 2009, "Bid to eradicate fuel poverty must include disabled people" Community Care 1754 11-11.

Cole R J, Robinson J, Brown Z, O'shea M, 2008, "Re-contextualizing the notion of comfort" Building Research \& Information 36 323-336.

Corgnati S P, Filippi M, Viazzo S, 2007, "Perception of the thermal environment in high school and university classrooms: Subjective preferences and thermal comfort” Building and Environment 42 951-959.

Critchley R, Gilbertson J, Grimsley M, Green G, 2007, “Living in cold homes after heating improvements: Evidence from Warm-Front, England's Home Energy Efficiency Scheme" Applied Energy 84 147-158.

de Dear R J, Brager G S, 1998, "Towards an adaptive model of thermal comfort and preference" ASHRAE Transactions 104 145-167.

Dodonov B, Opitz P, Pfaffenberger W, 2004, "How much do electricity tariff Increases in Ukraine hurt the poor?” Energy Policy 32 855-863. 
Domański B, 1997 Industrial Control over the Socialist Town-Benevolence or Exploitation? (Praeger, Westport, CT).

Ekamper P, van Poppel F, van Duin C, Garssen J, 2009, "150 Years of temperaturerelated excess mortality in the Netherlands" Demographic Research 21385 426.

Ekamper P, van Poppel F, van Duin C, Garssen J, 2009, "150 Years of temperaturerelated excess mortality in the Netherlands" Demographic Research 21385 426.

French A, 1995 Plans, Pragmatism and People (UCL Press, London).

Ganguli I, Terrell K, 2005 Wage Ceilings and Floors: The Gender Gap in Ukraine's Transition (IZA, Discussion Paper No. 1776, Bonn).

Gentile M, 2003, "Residential segregation in a medium-sized post-Soviet city: Ust'Kamenogorsk, Kazakhstan” Tijdschrift voor Economische en Sociale Geografie 94 589-605.

Gentile M, Mäkinen I, Ferlander S, 2009, "Experiences from Carrying Out a Large Survey in a Small City in East Ukraine: The Stakhanov Health Interview Survey 2009. Paper presented at the Third International Urban Geographies of Post-Communist States conference, Tartu, Estonia, 17-19 September 2009”.

Gentile M, Tammaru T, 2006, "Housing and ethnicity in the post-Soviet City: Ust'Kamenogorsk, Kazakhstan” Urban Studies 43 1757-1778.

Gillan J. 2000, "Household budget and house conditions in two Russian cities", in Poverty in Transition Ed. S Hutton (Routledge, London) pp 248-265.

Gray D, 1995 Reforming the Energy Sector in Transition Economies: Selected Experience and Lessons (World Bank, Washington, D.C.).

Harrington B E, Heyman B, Merleau-Ponty N, Stockton H, Ritchie N, Heyman A, 2005, "Keeping warm and staying well: Findings from the qualitative arm of the Warm Homes Project" Health \& and Social Care in the Community 13 259-267.

Healy J D, 2003, "Excess winter mortality in Europe: A cross country analysis identifying key risk factors" Journal of Epidemiology and Community Health 57 784-789.

Healy J D, 2004 Housing, Fuel Poverty and Health: A Pan-European Analysis (Ashgate, Aldershot).

Healy J D, Clinch J P, 2002, "Fuel poverty, thermal comfort and occupancy: Results of a national household-survey in Ireland" Applied Energy 73 329-343. 
Healy J D, Clinch J P, 2004, “Quantifying the severity of fuel poverty, its relationship with poor housing and reasons for non-investment in energy-saving measures in Ireland" Energy Policy 32 207-220

Heyman B, Harrington B E, Merleau-Ponty N, Stockton H, Richie N, Allan T F, 2005, "Keeping warm and staying well. Does home energy efficiency mediate the relationship between socio-economic status and the risk of poorer health?" Housing Studies 20 649-664.

Hitchings R, 2009, "Studying thermal comfort in context" Building Research \& Information 37 89-94.

Hung H S, Gilbertson J, Oreszczyn T, Green G, Ridley I, 2009, “A field study of thermal comfort in low-income dwellings in England before and after energy efficient refurbishment" Building and Environment 44 1228-1236.

Kapteyn A, Kooreman P, Willemse R, 1988, "Some methodological issues in the implementation of subjective poverty definitions" The Journal of Human Resources 23 222-242.

Kapteyn A, Kooreman P, Willemse R, 1988, "Some methodological issues in the implementation of subjective poverty definitions" The Journal of Human Resources 23 222-242.

Kovačević A, 2004 Stuck in the Past: Energy, Environment and Poverty in Serbia and Montenegro (United Nations Development Programme, Belgrade).

Liddell C, Morris C, 2010, "Fuel poverty and human health: A review of recent evidence” Energy Policy 38 2987-2997.

McKay S, 2004, "Poverty or preference: What do 'consensual deprivation indicators' really measure?” Fiscal Studies 25 201-223.

Milne G, Boardman B, 2000, "Making cold homes warmer: The effect of energy efficiency improvements in low-income homes. A report to the Energy Action Grants Agency Charitable Trust" Energy Policy 28 411-424.

Moezzi M, 2009, "Are comfort expectations of building occupants too high?" Building Research \& Information 37 79-83.

Nevin R, 2010, "Energy-efficient housing stimulus that pays for itself” Energy Policy 38 4-11.

O’Hara S, Ivlevs A, Gentile M, 2009, “The impact of global economic crisis on remittances in the Commonwealth of Independent States" Eurasian Geography and Economics $\mathbf{5 0} 447-463$.

Pachauri S, Spreng D, 2004, "Energy use and energy access in relation to poverty" Economic and Political Weekly 39 271-278. 
Pachauri S, Spreng D, 2004, "Energy use and energy access in relation to poverty" Economic and Political Weekly 39 271-278.

Pertsik E, 1980 Gorod v Sibiri [The City in Siberia] (Mysl, Moscow).

Poputoaia D, Bouzarovski S, 2010, "Regulating district heating in Romania: Legislative challenges and energy efficiency barriers" Energy Policy 38 38203829.

Sagar A D, 2005, “Alleviating energy poverty for the world's poor” Energy Policy 33 1367-1372.

Sen A, 2009 The Idea of Justice (Belknap Press/Harvard University Press, Cambridge).

Spector P E, 1994, "Using self-report questionnnaires in OB research: A comment on the use of a controversial method" Journal of Organizational Behavior 15 385-392.

Stern J, Davis J R, 1998, "Economic reform of the electricity industries of Central and Eastern Europe" Economics of Transition 6 427-460.

Stewart J, Habgood V, 2008, "Benefits of a health impact assessment in relation to fuel poverty: Assessing Luton's Affordable Warmth Strategy and the need for a national mandatory strategy" Perspectives in Public Health 128 123-129.

Sýkora L, Bouzarovski S, 2012, "Multiple transformations: conceptualising the postcommunist urban transition" Urban Studies 49 43-60.

Tirado Herrero S, Ürge-Vorsatz D, 2011, "Trapped in the heat: A post-communist type of fuel poverty" Energy Policy http://dx.doi.org/10.1016/j.enpol.2011.08.067 .

Tsenkova S, Turner B, 2004, "The future of social housing in Eastern Europe: reforms in Latvia and Ukraine" European Journal of Housing Policy 4 133-149.

Vågero D, Kislitsyna O, 2005, "Self-reported heart symptoms are strongly linked to past and present poverty in Russia: Evidence from the 1998 Taganrog interview survey" European Journal of Public Health 15 418-423.

von Hirschhausen C, Wälde T, 2001, "The end of transition: An institutional interpretation of energy sector reform in Eastern Europe and the CIS" MoctMost: Economic Policy in Transitional Economies 11 93-110.

Walker G, 2008, "Decentralised systems and fuel poverty: Are there any links or risks?” Energy Policy 36 4514-4517.

Walker G, Day R, 2012, "Fuel poverty as injustice: Integrating distribution, recognition and procedure in the struggle for affordable warmth" Energy Policy DOI: 10.1016/j.bbr.2011.1003.1031.. 
Walker R, 1987, "Consensual approaches to the definition of poverty: Towards an alternative methodology” Journal of Social Policy 16 213-226.

Wilhite H, Nakagami H, Masuda T, Yamaga Y, Haneda H, 1996, “A cross-cultural analysis of household energy use behaviour in Japan and Norway" Energy Policy 24 795-803.

Wilkinson P, Pattenden S, Armstrong B, Fletcher A, Kovats S R, Mangtani P, et al., 2004, "Vulnerability to winter mortality in elderly people in Britain: population based study" BMJ 647.

Wright A, 2008, "What is the relationship between built form and energy use in dwellings?" Energy Policy 36 4544-4547.

Wright F, 2004, "Old and cold: Older people and policies failing to address fuel poverty" Social Policy \& Administration 38 488-503.

Wu X, Lampietti J, Meyer A S, 2004, "Coping with the cold: Space heating and the urban poor in developing countries" Energy Economics 26 345-357. 
Table 1: The distribution of the dependent variable. Question: 'In your opinion, the usual wintertime indoor temperature in your home is...'

\begin{tabular}{|l|l|l|}
\hline Original answers & Frequency & Percent \\
\hline Too warm & 9 & 0.3 \\
\hline Sufficiently warm & 1680 & 56.0 \\
\hline Tolerably cold & 876 & 29.2 \\
\hline Too cold & 435 & 14.5 \\
\hline Total & 3000 & 100 \\
\hline Dichotomized answers & Frequency & Percent \\
\hline Warmer & 1689 & 56.3 \\
\hline Colder & 1311 & 43.7 \\
\hline Total & 3000 & 100 \\
\hline
\end{tabular}

Source: SHIS.

Table 2: Age of the housing stock included in the sample

\begin{tabular}{|l|l|l|}
\hline Period & Frequency & Percent \\
\hline Czarist times (pre-1918) & 63 & 2.3 \\
\hline Inter-war (1918-1939) & 202 & 7.4 \\
\hline $\begin{array}{l}\text { Late Stalin and interregnum } \\
\text { period (1940-1957) }\end{array}$ & 458 & 16.8 \\
$\begin{array}{l}\text { Khrushchev and early post- } \\
\text { Khrushchev (1958-1968) }\end{array}$ & 763 & 28.0 \\
\hline Mature Soviet (1969-1979) & 602 & 22.1 \\
\hline Late Soviet (1980-1991) & 577 & 21.2 \\
\hline Post-Soviet (post-1991) & 63 & 2.3 \\
\hline
\end{tabular}

Source: SHIS. 
Table 3: Bivariate logistic regression statistics, unadjusted coefficients.

\begin{tabular}{|c|c|}
\hline Independent variables & $\operatorname{Exp}(B)$ \\
\hline Male gender (vs. female) & $0.776 * * *$ \\
\hline Age & $1.014 * * *$ \\
\hline Household size & $0.756 * * *$ \\
\hline $\begin{array}{l}\text { Income (in 100s of UAH per } \\
\text { month) }\end{array}$ & $0.940 * * *$ \\
\hline $\begin{array}{l}\text { Need to borrow money during } \\
\text { past } 12 \text { months (vs. never } \\
\text { needed) }\end{array}$ & $3.023 * * *$ \\
\hline $\begin{array}{l}\text { Owned dwelling (vs. rental } \\
\text { housing) }\end{array}$ & $0.293 * * *$ \\
\hline Floor space (sqm) & $0.962 * * *$ \\
\hline $\begin{array}{l}\text { District heating (vs. no district } \\
\text { heating) }\end{array}$ & $1.500 * * *$ \\
\hline $\begin{array}{l}\text { Khrushchev era housing (vs. } \\
\text { other housing) }\end{array}$ & $1.952 * * *$ \\
\hline $\begin{array}{l}\text { Dwelling perceived as humid } \\
\text { (vs. not perceived as humid) }\end{array}$ & $3.933 * * *$ \\
\hline $\begin{array}{l}\text { Born in Russia (vs. born } \\
\text { elsewhere) }\end{array}$ & $1.547 * * *$ \\
\hline $\begin{array}{l}\text { Perceived poor health (vs. } \\
\text { health not perceived as poor) }\end{array}$ & $1.866^{* * *}$ \\
\hline $\begin{array}{l}\text { Daytime temperature on } \\
\text { interview date }\end{array}$ & $0.961 * * *$ \\
\hline $\begin{array}{l}\text { Daytime cloud cover (four } \\
\text { levels from clear to } \\
\text { cloudy/overcast) }\end{array}$ & $0.804 * * *$ \\
\hline
\end{tabular}

Dependent variable: perceived wintertime thermal discomfort indoors.

$*=$ significant at 5 percent level;

$* *$ = sig. at 1 percent level;

$* * *=$ sig. at 0.1 percent level.

Source: SHIS.

Table 4: Multiple logistic regression models, mutually adjusted coefficients. 


\begin{tabular}{|c|c|c|c|c|c|c|}
\hline $\begin{array}{l}\text { Independent } \\
\text { variables }\end{array}$ & Model 1 & Model 2 & Model 3 & Model 4 & Model 5 & Model 6 \\
\hline $\begin{array}{l}\text { Male gender } \\
\text { (vs. female) }\end{array}$ & $0.891 * *$ & 1.012 & 0.995 & 1.098 & 1.114 & 1.114 \\
\hline Age & $1.006 * *$ & $1.011 * * *$ & $1.014 * * *$ & $1.017 * * *$ & $1.013 * * *$ & $1.013 * * *$ \\
\hline $\begin{array}{l}\text { Household } \\
\text { size }\end{array}$ & $0.791 * * *$ & $0.840 * * *$ & $0.797 * * *$ & 0.906 & 0.908 & 0.906 \\
\hline $\begin{array}{l}\text { Income (in } \\
100 \text { s of UAH } \\
\text { per month) }\end{array}$ & & $0.965^{* * *}$ & $0.971 * * *$ & $0.964 * * *$ & $0.965 * * *$ & $0.965 * * *$ \\
\hline $\begin{array}{l}\text { Need to } \\
\text { borrow money } \\
\text { during past } 12 \\
\text { months (vs. } \\
\text { never needed) }\end{array}$ & & $2.911 * * *$ & $3.005 * * *$ & $2.831 * * *$ & $2.797 * * *$ & $2.779 * * *$ \\
\hline $\begin{array}{l}\text { Owned } \\
\text { dwelling (vs. } \\
\text { rental } \\
\text { housing) }\end{array}$ & & & $0.270 * * *$ & $0.368 * * *$ & $0.366^{* * *}$ & $0.356^{* * *}$ \\
\hline $\begin{array}{l}\text { Floor space } \\
\text { (sqm) }\end{array}$ & & & & $0.973 * * *$ & $0.973 * * *$ & $0.973 * * *$ \\
\hline $\begin{array}{l}\text { Central } \\
\text { heating (vs. no } \\
\text { central } \\
\text { heating) }\end{array}$ & & & & 1.151 & 1.145 & 1.171 \\
\hline $\begin{array}{l}\text { Khrushchev } \\
\text { era housing } \\
\text { (vs. other } \\
\text { housing) }\end{array}$ & & & & $1.574 * * *$ & $1.557 * * *$ & $1.553 * * *$ \\
\hline $\begin{array}{l}\text { Dwelling } \\
\text { perceived as } \\
\text { humid (vs. not } \\
\text { perceived as } \\
\text { humid) } \\
\end{array}$ & & & & $2.797 * * *$ & $2.848 * * *$ & $2.718 * * *$ \\
\hline $\begin{array}{l}\text { Born in Russia } \\
\text { (vs. born } \\
\text { elsewhere) }\end{array}$ & & & & & 1.089 & 1.099 \\
\hline $\begin{array}{l}\text { Perceived } \\
\text { poor health } \\
\text { (vs. health not } \\
\text { perceived as } \\
\text { poor) }\end{array}$ & & & & & $1.289 *$ & $1.303 *$ \\
\hline Daytime & & & & & & 0.998 \\
\hline
\end{tabular}




\begin{tabular}{|l|l|l|l|l|l|l|}
\hline $\begin{array}{l}\text { temperature } \\
\text { on interview } \\
\text { date }\end{array}$ & & & & & & \\
\hline $\begin{array}{l}\text { Daytime cloud } \\
\text { cover (four } \\
\text { levels from } \\
\text { clear to } \\
\text { cloudy/overca } \\
\text { st) }\end{array}$ & & & & & $0.888^{*}$ \\
\hline & & & & & & \\
\hline Nagelkerke $\mathrm{R}^{2}$ & 0.039 & 0.187 & 0.222 & 0.290 & 0.292 & 0.294 \\
\hline $\begin{array}{l}-2 \text { Log- } \\
\text { likelihood }\end{array}$ & 4020.776 & 2959.477 & 2791.429 & 2387.595 & 2383.046 & 2378.452 \\
\hline
\end{tabular}

Dependent variable: perceived wintertime thermal discomfort indoors.

$*$ = significant at 5 percent level;

$* *=$ sig. at 1 percent level;

$* * *=$ sig. at 0.1 percent level.

Source: SHIS. 
Table 5: Material wealth in Stakhanov by gender.

\begin{tabular}{|c|c|c|c|}
\hline \multicolumn{2}{|l|}{ Indicator/Gender } & Men & Women \\
\hline \multicolumn{2}{|c|}{ Average monthly personal income (in grivnya) } & 1610 & 818 \\
\hline \multicolumn{2}{|c|}{ Average monthly household income (in grivnya) } & 2484 & 1952 \\
\hline \multirow{4}{*}{$\begin{array}{l}\text { Needing to borrow money } \\
\text { for daily consumption }\end{array}$} & Never & $68,6 \%$ & $60,0 \%$ \\
\hline & Rarely & $21,0 \%$ & $12,6 \%$ \\
\hline & Sometimes & $16,5 \%$ & $20,0 \%$ \\
\hline & Often & $3,9 \%$ & $7,4 \%$ \\
\hline
\end{tabular}

Source: SHIS. 
Figure 1: Khrushchev-era apartments in central Stakhanov (photo by Michael Gentile, March 2009).

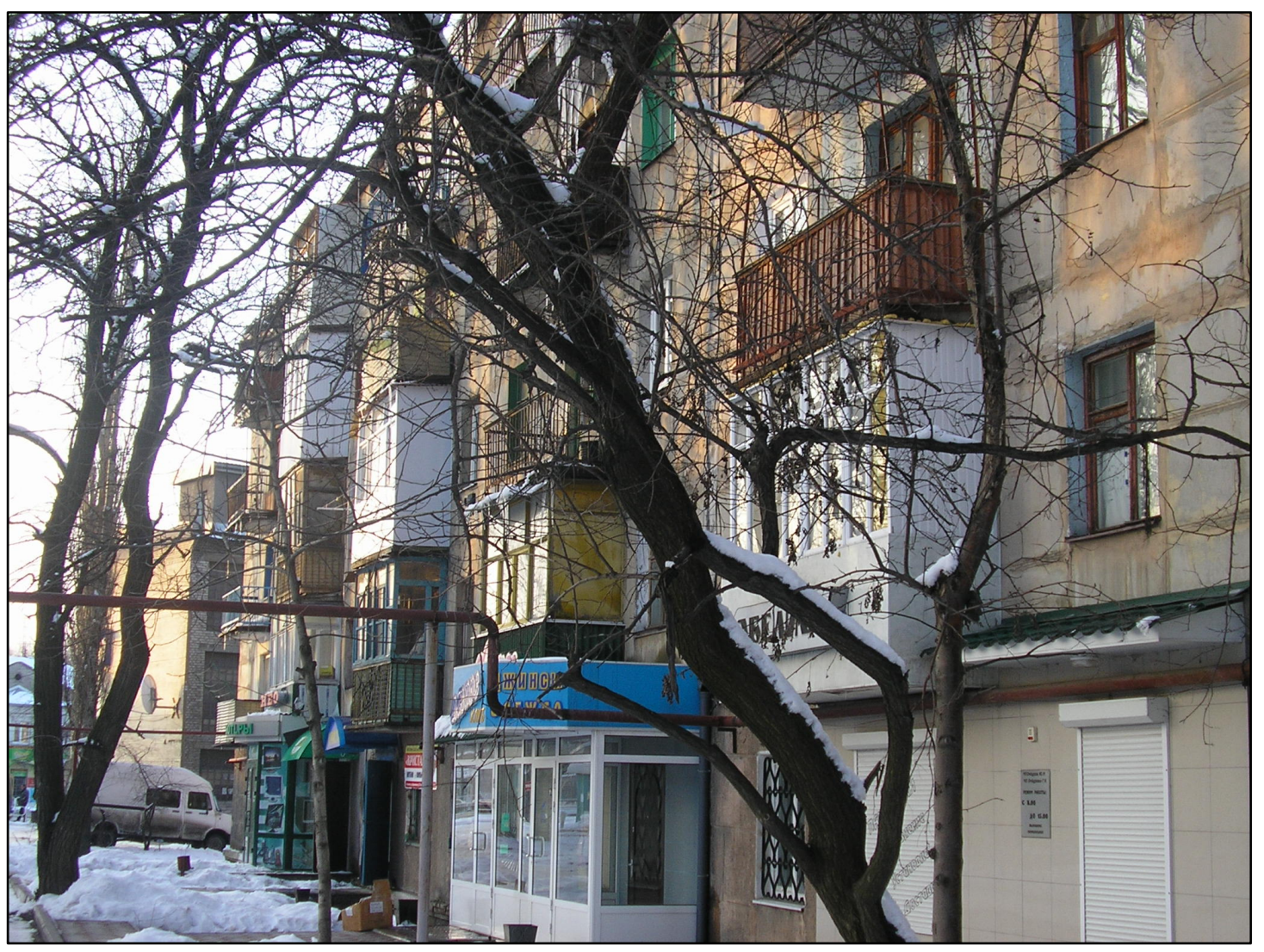


Figure 2: High-rise apartment blocks from the 1970s in Stakhanov (photo by Michael Gentile, March 2009).

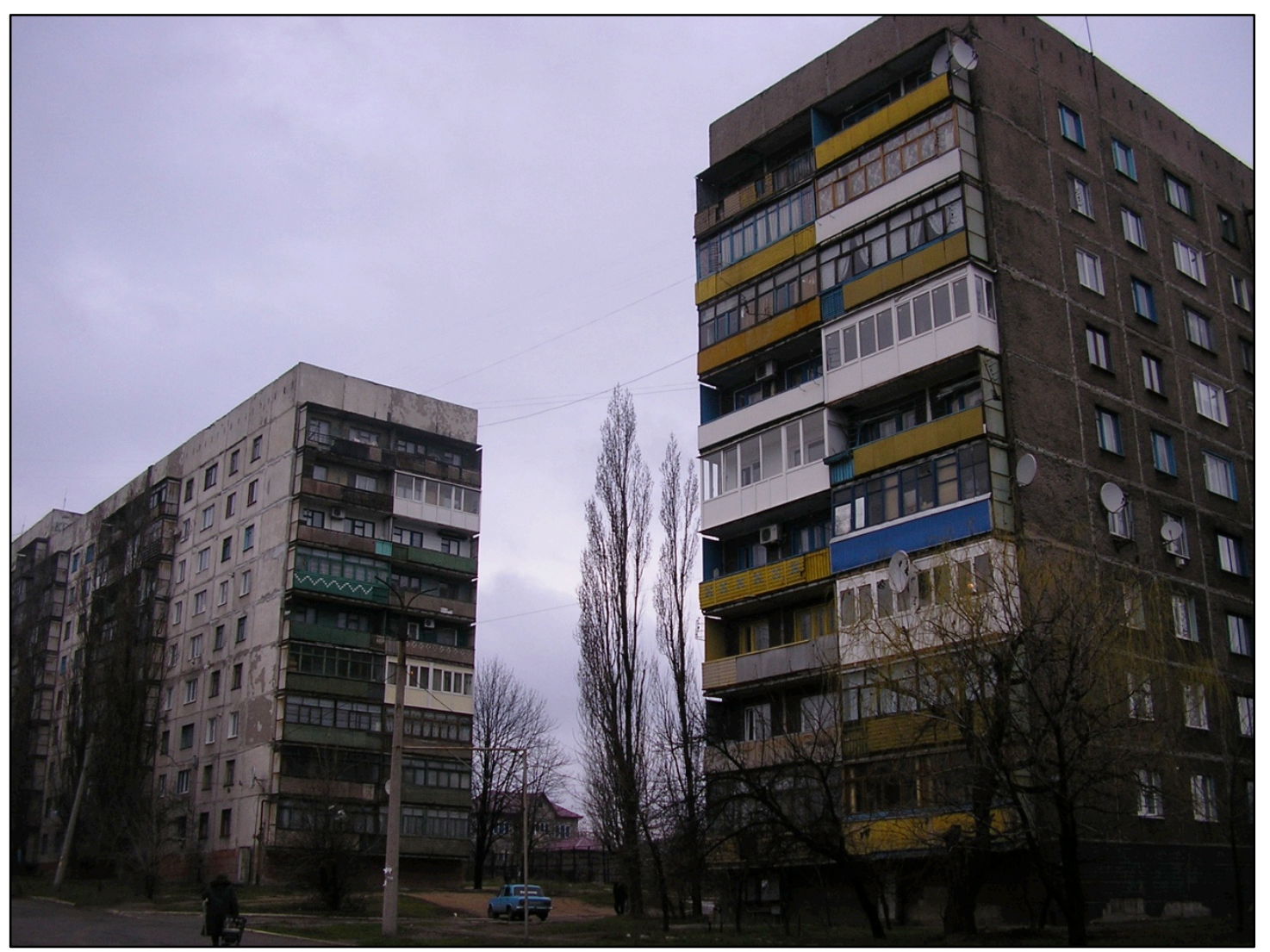

